\title{
Market-shaping phases-a qualitative meta-analysis and conceptual framework
}

\author{
Alexander Flaig $^{1}\left[\right.$ Daniel Kindström ${ }^{1} \cdot$ Mikael Ottosson $^{1}$
}

Received: 22 June 2020 / Accepted: 25 October 2021 / Published online: 21 December 2021

(c) The Author(s) 2021

\begin{abstract}
This study explores the potential existence of reoccurring patterns in market-shaping processes by employing a qualitative meta-analysis to analyze 79 case studies on market-shaping. Through the evidence-based synthesis of qualitative data, we extract 20 generalized market-shaping activities that inform and form the foundation of a three-phased market-shaping process. This conceptual framework divides the market-shaping process into the phases of infusion, formation and retention. By applying our conceptual framework to the qualitative dataset, we explore the presence of market-shaping phases and provide further insights into the interdependences and dynamics between multiple, simultaneously occurring, marketshaping processes. By providing a structured market-shaping process, we attempt to reduce the overall complexity of the market-shaping phenomenon and facilitate the operationalization of the phenomenon for further market-shaping research. Additionally, our conceptualization provides practitioners with a framework to analyze the market-shaping efforts of other market actors and support the design of their own market-shaping strategies.
\end{abstract}

Keywords Market-shaping $\cdot$ Qualitative meta-analysis $\cdot$ Shaping markets $\cdot$ Market driving $\cdot$ Market innovation $\cdot$ Market creation $\cdot$ Market strategy

\section{Introduction}

Despite growing interest within both academia and practice, market-shaping is in many ways still a nascent domain. Over the past few decades, research has been increasingly perceiving markets as complex adaptive systems in general (Mollinger-Sahba et al., 2021; Nenonen et al., 2020) and as configurations of actors and resources in particular (Andersson et al., 2008; Storbacka \& Nenonen, 2011a). Consequently, research is moving from a static and dyadic market view towards a view of markets as ongoing and dynamic processes (Kjellberg \& Helgesson, 2006; Kjellberg et al., 2015) with plastic characteristics (Mele et al., 2015; Nenonen, et al., 2014). This plasticity enables the notion of

Alexander Flaig

alexander.flaig@liu.se

Daniel Kindström

daniel.kindstrom@liu.se

Mikael Ottosson

mikael.ottosson@liu.se

1 Department of Management and Engineering, Linköping University, 58183 Linköping, Sweden "shapeable markets" and has gained traction through seminal works in various disciplines, such as economic sociology (Callon, 1998), marketing (Jaworski et al., 2000; Kjellberg \& Helgesson, 2006) and strategy (Santos \& Eisenhardt, 2009) and can, in part, be traced back to Alderson and Cox's (1948, p. 142) view on markets:

"[...] a market changes day by day through the very fact that goods are bought and sold. While evaluation is taking place within a marketing structure, the structure itself is being rendered weaker or stronger and the changes in organization which follow will have an impact on tomorrow's evaluations."

Consequently, activities on a market, often aggregated into distinct market practices (Kjellberg \& Helgesson, 2006), are constantly shaping and reshaping markets by organizing actors and resources in certain ways, leading to new or altered market configurations (Nenonen et al., 2019b).

Recently, some scholars have begun to operationalize the notion of shapeable markets into strategic applications of the phenomenon (Flaig et al., 2021; Jaworski et al., 2020; Nenonen $\&$ Storbacka, 2020). In this way, market-shaping is considered 
to be an actor-driven strategic process aimed at shaping a market towards a favorable outcome (Flaig et al., 2021). This strategic process encompasses intentional and purposive activities aimed at altering a market configuration in order to shape a market (Hawa et al., 2020; Jaworski et al., 2020). Storbacka and Nenonen (2011b) termed this process "market scripting" and conceptualized it as a sequence of three phases. Their conceptualized sequence is rooted in evolutionary economics and follows the origination-adoption-retention sequence depicting the trajectory of economic systems (Dopfer et al., 2004). While some authors have hinted that market-shaping processes might display similar phases (Kindström et al., 2018; Nenonen \& Storbacka, 2020; Nenonen et al., 2019b), research inquiries into the possibility of reoccurring market-shaping phases have received little attention in market-shaping research.

One of the few studies investigating markets through sequential analysis (Depeyre \& Dumez, 2009) discovered that market dynamics result from patterns of strategic (re) actions of focal market actors, thereby indicating the potential existence of reoccurring patterns that could allude to overarching actor-driven market-shaping phases. This relates to a chaos theory perspective of complex systems, arguing that complex systems display traceable repetitive patterns that provide information about the conditions and likely paths that can lead to certain occurrences (Levy, 1994). Consequently, identifying patterns becomes especially intriguing, when associated to the underlying evolutionary phase of a system as it might indicate the present conditions necessary for certain occurrences. Focusing on market-shaping, exploring the existence of patterns in actor-driven marketshaping processes would provide further insights into purposive market-shaping and the resulting market dynamics.

Consequently, this study sets out to investigate the existence of overarching market-shaping phases in actor-driven market-shaping processes by posing the following research question:

\section{What activity patterns can be identified in actor-driven market-shaping processes?}

To explore the notion of reoccurring patterns in marketshaping processes, a significant amount of qualitative evidence is needed in order to provide reliable and generalizable insights. With most of the studies investigating the marketshaping phenomenon being qualitative (Sprong et al., 2021), a qualitative meta-analysis approach is deemed appropriate for investigating potential phases in market-shaping processes (Rauch et al., 2014; Combs et al., 2019). This allows us to comprehensively capture and synthesize the literature on the market-shaping phenomenon, as a qualitative meta-analysis encompasses a systematic literature review (Tranfield et al., 2003) and a qualitative meta-synthesis of empirical data (Hoon, 2013; Rauch et al., 2014). Qualitative meta-analyses provide the same rigorous methodological principles as quantitative meta-analyses while synthesizing qualitative evidence to test or build new theory (Combs et al., 2019). Based on an in-depth review of 79 qualitative studies, we systematically extract and synthesize market-shaping activities to provide an overview of analytically generalized market-shaping activities. Subsequently, we leverage the synthesized market-shaping activities to identify patterns in the empirical market-shaping processes in our literature sample. Finally, we develop a conceptual framework delineating an actor-driven three-phased market-shaping process.

This article contributes to the literature in two ways in particular. First, to the best of our knowledge, it provides the first qualitative meta-analysis that systematically synthesizes existing qualitative market-shaping research. By doing so, we provide an overview of analytically generalized market-shaping activities through an evidence-based aggregation of qualitative data (Rauch et al., 2014). Hereby, we attempt to consolidate the conceptual and disciplinary diversity of market-shaping activities and mitigate the current fragmentation and complexity of the market-shaping field.

Second, by systematically synthesizing previous case studies on the market-shaping phenomenon, this study investigates patterns of activities that enable a delineation of the market-shaping process into distinct phases. Based on this meta-synthesis, we provide a conceptual framework of the market-shaping process as actor-driven and consisting of three phases, beginning at the infusion of market change, followed by market formation and ending with market retention. The framework attempts to provide a more structured view on the market-shaping process, while maintaining its dialectical nature of change and stability. In other words, we attempt to unify the traditional and static, but more simplistic market perspective with the more recent, complex and malleable market conceptualization. Thereby, we answer calls in this special issue for broader and more dynamic market conceptualizations in an attempt to reconcile these two perspectives (Wieland et al., 2021).

The paper is structured as follows. First, we present our research method followed by the results of our meta-analysis, in which each phase of the market-shaping process is presented with its respective market-shaping activities. Then, we present our conceptual framework delineating the actor-driven and three-phased market-shaping process. We then conclude by discussing our theoretical and managerial implications and possible avenues for future research.

\section{Research method}

The trustworthiness of any literature review lies in the methodological rigor and transparency of the process of selection and analysis (Snyder, 2019). A qualitative 
meta-analysis is used to systematically synthesize qualitative research by accumulating, organizing and interpreting studies in order to achieve "a level of understanding that transcends the results of the individual studies", (Rauch et al., 2014, p. 334). We follow an explanatory synthesis approach (Rousseau et al., 2008), as our point of departure is the assumption of underlying market-shaping phases, which we then attempt to identify through an interrogative data analysis process. Evidently, the qualitative evidence of the selected case studies will display theoretical heterogeneity as "all facts, observations and data are theory-laden", (Rousseau et al., 2008, p. 487). However, precisely this theoretical pluralism provides diverse perspectives on reality, which enable the identification of regularities (Bhaskar, 1998). Thus, rather than invalidating the selected literature sample, it strengthens the analysis when similarities emerge across the theoretically and empirically diverse case studies.

A qualitative meta-analysis follows a similar research process as a quantitative meta-analysis or a systematic review (Rauch et al., 2014; Tranfield et al., 2003). The first steps in a qualitative meta-analysis are akin to the searching and screening stage in a systematic literature review (Hoon, 2013; Rauch et al., 2014; Tranfield et al., 2003) and thus ensure transparency and rigor in the selection of the reviewed literature. The subsequent steps encompass the meta-synthesis (Rauch et al., 2014), focusing on the analysis and synthesis of the qualitative data. This review is therefore conducted in three main stages, namely, the search, the screening and the synthesis stages (Tranfield et al., 2003; Watson et al., 2018).

\section{Searching stage}

Despite several decades of marketing research investigating the market-shaping phenomenon, a unified concept and definition for market-shaping remains lacking. In order to frame the market-shaping phenomenon and construct a search query, we began by investigating the current understanding of the market-shaping phenomenon. An initial scoping of recent publications (e.g., Breidbach \& Tana, 2021; Kindström et al., 2018; Nenonen et al., 2020; Sprong et al., 2021) identified the concepts encompassing the marketshaping phenomenon. Here, the most common concepts related to the market-shaping phenomenon were marketshaping (Kjellberg \& Helgesson, 2007), market innovation (Kjellberg et al., 2015), market driving (Hills \& Sarin, 2003; Jaworski et al., 2000), market scripting (Storbacka $\&$ Nenonen, 2011b), proactive market orientation (Narver et al., 2004), market formation (Struben et al., 2020) and market creation (Humphreys, 2010).

We conducted an initial search using the Web of Science database and extracted a first literature sample filtered by the exclusion criteria in Table 2. The extracted literature sample was then used to conduct a co-occurrence analysis in order to identify the relationships between different articles and to provide a conceptual structure of the field (Zupic \& Čater, 2015). Here, we screened the generated network map (see Fig. 4 in Appendix) for standalone concepts describing market-shaping processes. As the network map did not reveal any relationships to other concepts that matched this condition, we deemed the previously selected concepts appropriate for the subsequent literature search. Evidently, there may be several additional concepts that can relate to

Table 1 Overview of seven key market-shaping terms

\begin{tabular}{|c|c|c|}
\hline Term & Authors & Description \\
\hline Market-shaping & Nenonen et al. (2019b) & $\begin{array}{l}\text { "Market-shaping implies purposive actions by a focal firm to change market } \\
\text { characteristics by re-designing the content of exchange, and/or re-configuring } \\
\text { the network of stakeholders involved, and/or re-forming the institutions that } \\
\text { govern all stakeholders' behaviors in the market." }\end{array}$ \\
\hline Market driving & Jaworski et al. (2000) & $\begin{array}{l}\text { "[...] influencing the structure of the market and/or the behavior(s) of market } \\
\text { players in a direction that enhances the competitive position of the busi- } \\
\text { ness." (p. 45) }\end{array}$ \\
\hline Market scripting & Storbacka and Nenonen (2011b) & $\begin{array}{l}\text { "[...] the conscious activities conducted by a market actor in order to alter the } \\
\text { current market configuration in its favor." (p. 259) }\end{array}$ \\
\hline Proactive market orientation & Narver et al. (2004) & $\begin{array}{l}\text { Understanding and satisfying customers' latent needs by "leading customers } \\
\text { in their satisfaction." (p. 336) }\end{array}$ \\
\hline Market innovation & Kjellberg et al. (2015) & $\begin{array}{l}\text { "[...] comprises the successful change of existing market structure, the intro- } \\
\text { duction of new market devices, the alteration of market behavior, and the } \\
\text { reconstitution of market agents." (p. 6) }\end{array}$ \\
\hline Market creation & Humphreys (2010) & $\begin{array}{l}\text { "[...] the creation of new markets as a political and social process, one } \\
\text { affected by the environment that exists outside the firm or industry." (p. 1) }\end{array}$ \\
\hline Market formation & Lee et al. (2018) & $\begin{array}{l}\text { "[...] creation of a shared market infrastructure-material and sociocogni- } \\
\text { tive elements supporting the functioning of a stable market—-that benefits } \\
\text { market actors." (p. 243) }\end{array}$ \\
\hline
\end{tabular}


Table 2 Inclusion and exclusion criteria

\begin{tabular}{lll}
\hline Criterion & Inclusion & Exclusion \\
\hline $\begin{array}{l}\text { Study type } \\
\text { Quality }\end{array}$ & $\begin{array}{c}\text { Peer-reviewed journal article } \\
\text { Journal rated 2 or higher in CABS (2018) in the fields of "Market- } \\
\text { ing", "Strategy", "General Management, Ethics, Gender and } \\
\text { Social Responsibility", "Organization" "Innovation" }\end{array}$ & $\begin{array}{c}\text { Conference proceedings, book chapters, books, working papers } \\
\text { Any other journal not included in the CABS (2018) ranking in } \\
\text { the selected research fields }\end{array}$ \\
$\begin{array}{l}\text { Language } \\
\text { Relevance }\end{array}$ & $\begin{array}{c}\text { One of the seven market-shaping terms is used either in the theo- } \\
\text { retical framework or with an explanatory focus }\end{array}$ & $\begin{array}{c}\text { Any other language } \\
\text { Any article not basing the terminology on the conceptualiza- } \\
\text { tion of the selected market-shaping terms }\end{array}$ \\
\hline
\end{tabular}

the market-shaping phenomenon. However, as "no review paper can be truly comprehensive", (Hulland \& Houston, 2020, p. 3), we focus on these selected concepts as they are commonly referred to as encompassing the market-shaping phenomenon, thus providing an appropriate starting point for the literature search (see Table 1).

The chosen terms were searched within titles, abstracts and keywords using the following search string across the Web of Science database:

("shap* market*" OR "driv* market*" OR "script*market*" OR "market shap*" OR "market driv*" OR "market script*" OR "proactive market orientation" OR "market innovat*" OR "innovat* market*" OR "market form*" OR "form* market*" OR “market creat*" OR "creat* market*”).

This search returned 5524 articles.

\section{Screening stage}

The screening was conducted in two stages. First, the initial sample was refined according to the exclusion criteria in Table 2. In order to increase the quality of the returned results for the literature review, the Chartered Association of Business Schools' Academic Journal Guide (CABS, 2018) was used. While the ranking of journals in the Academic Journal Guide includes subjective evaluations, it combines the impact factor and the rigor of peer review, thereby integrating objective measures and increasing the reliability and validity of the ratings (Podsakoffet al., 2005). Thus, journals pertaining to the fields "marketing", "strategy", "general management, ethics, gender and social responsibility", "organizations" and "innovation" rated 2 or higher were selected, as they included the journals in which seminal
Fig. 1 Systematic literature selection process

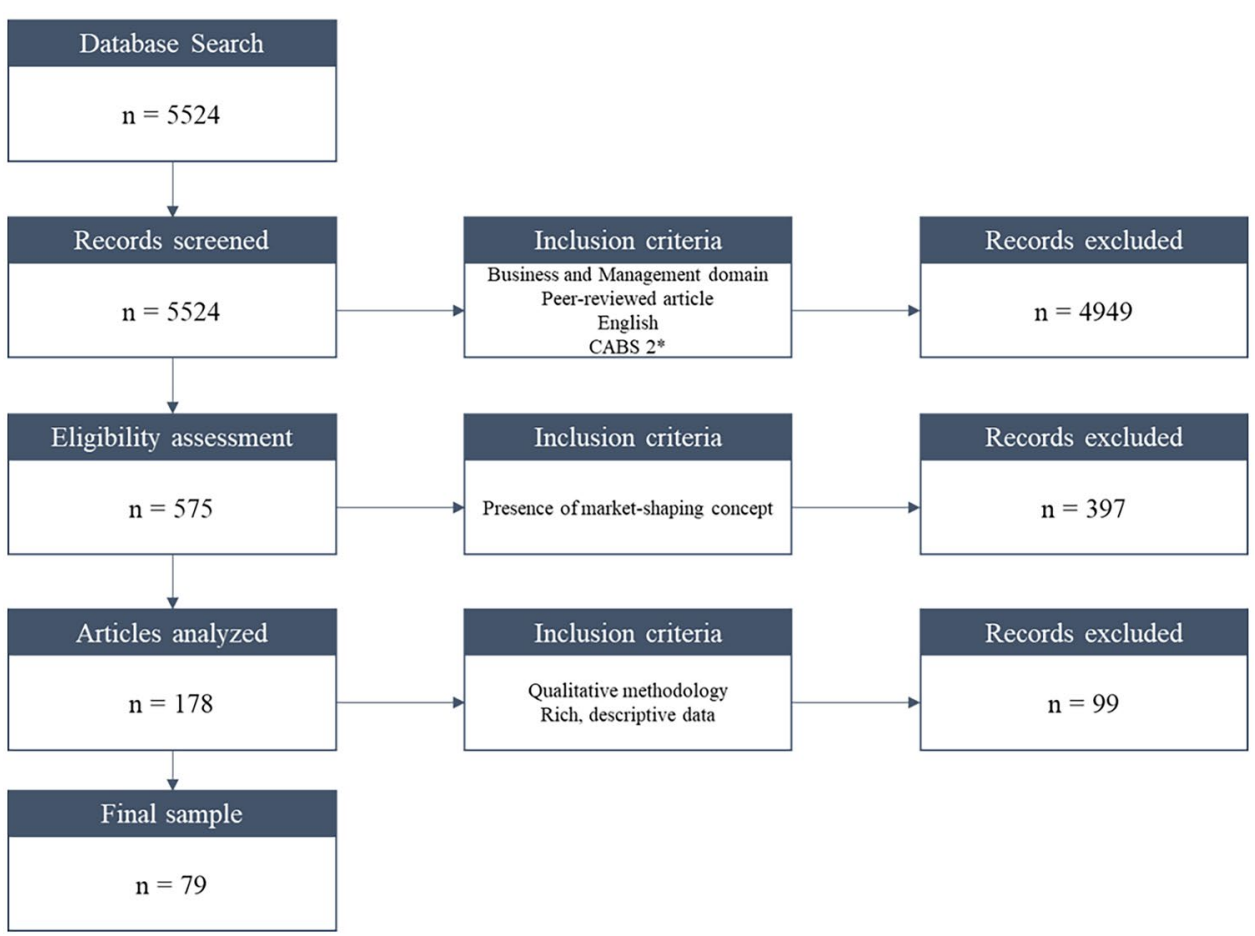


papers on the respective market-shaping concepts were published. The first stage of the screening resulted in 575 articles.

Second, an initial screening of the article titles, keywords and abstracts with reference to the inclusion criterion "relevance" (see Table 2) was conducted.

In cases of uncertainty, the article in question was carefully read and analyzed for adherence to the defined inclusion criteria in order to increase the reliability of the sample. Here, relevance is defined by the application of market-shaping concepts and their related terminology in order to exclude any article that coincidentally uses the same terms with no actual relation to a market-shaping concept. This screening resulted in a sample of 178 articles for in-depth examination.

Finally, qualitative studies providing rich and thick case descriptions necessary for the meta-analysis were selected for the final sample. This step resulted in the final sample of 79 articles (see Fig. 1).

\section{Synthesis stage}

In order to conduct a meta-synthesis, evidence from the selected sample has to be extracted, coded and categorized
(Hoon, 2013; Rauch et al., 2014). The meta-synthesis followed an interpretative approach and was thus conducted inductively (Combs et al., 2019). First, we identified and extracted market-shaping activities that were described in the findings and discussion section of the respective studies. Subsequently, we aggregated the extracted market-shaping activities, based on similarities in their characteristics, into overarching market-shaping activities (see Table 3). Throughout this process, we used Excel spreadsheets to organize the extracted data and to reduce human bias and error (Tranfield et al., 2003).

During the in-depth reading of the literature sample in combination with the data extraction process, evidence for reoccurring patterns in market-shaping processes began to emerge. The emergent patterns strongly resembled the phases pertinent to trajectories of complex evolutionary systems (Dopfer et al., 2004). These trajectories start at the origination of change, followed by the adoption of change and ending with the retention of the change (Dopfer et al., 2004). This underlying logic can be found in many other three-phased processes, such as in market development processes (Fligstein, 1996), market formation processes (Bleda \& Del Río, 2013) or market scripting processes (Storbacka

Table 3 Extract of data analysis - coding table for the activity "developing a vision"

\begin{tabular}{|c|c|c|}
\hline Original quote & Extracted Activity & Overarching activity \\
\hline $\begin{array}{l}\text { "The beginning of the interaction stage was marked by two main types of market } \\
\text { work. First, the four founders engaged in envisioning and establishing their objec- } \\
\text { tive of not using cork." (Baker and Nenonen, p. 245) }\end{array}$ & $\begin{array}{l}\text { Envisioning a future market } \\
\text { based on an objective }\end{array}$ & Developing a vision \\
\hline $\begin{array}{l}\text { "[...] winemakers imagine a future that does not exist and then make it tangible, thus } \\
\text { advancing their vision [...]" (Humphreys \& Carpenter, 2018, p. 148) }\end{array}$ & Imagining a future market & \\
\hline $\begin{array}{l}\text { "First, every organization in the sample contained individuals who disagreed with the } \\
\text { status quo and envisioned an alternative." (Canales, 2016, p. 1556) }\end{array}$ & Envisioning an alternative market & \\
\hline $\begin{array}{l}\text { "Pioneering producers need to envision and develop designs and production pro- } \\
\text { cesses that deviate from existing practices and logics in their industry." (Weber } \\
\text { et al., 2008, p. 542) }\end{array}$ & Envisioning an alternative market & \\
\hline $\begin{array}{l}\text { "Still, they also desired to alter the broad conditions of a market for the advantage of } \\
\text { other actors, a motive that often guides entrepreneurs and avid consumers." (Maciel } \\
\text { \& Fischer, 2020, p. 46) }\end{array}$ & Vision of market change & \\
\hline $\begin{array}{l}\text { "The Good African brand vision allowed Andrew to develop 'building blocks' in its } \\
\text { achievement, instigating the creation of an agencement [layout], and steering diverse } \\
\text { market shaping activities." (Onyas \& Ryan, 2015b, p. 150) }\end{array}$ & Vision steers market-shaping & \\
\hline $\begin{array}{l}\text { "The goal was to develop a label for the coffee that could be used by existing brands } \\
\text { as an extension of their product line. [...] Consumers would pay a premium price } \\
\text { for the labeled coffee, while producers would be paid a minimum price that covered } \\
\text { the costs for development of their livelihoods." (Ingenbleek \& Reinders, 2013, p. } \\
465 \text { ) }\end{array}$ & Envisioning a future market & \\
\hline $\begin{array}{l}\text { "We were just a bunch of crazy people who wanted to do things and little by little } \\
\text { we came to a vision of what the modern circus could be." (Babinski, 2004, p. } 89 \\
\text { through Baker et al., 2019) }\end{array}$ & Development of a vision & \\
\hline $\begin{array}{l}\text { "CleanFarm's strategy centered on 'planting visions and ideas at central places,' } \\
\text { including ministries and parliament, as well as farmers' associations and NGOs } \\
\text { active in the field of environmental protection. The objective was not only to push } \\
\text { for regulation, but also to promote the vision that pig production could be expanded } \\
\text { without harming the environment, while positioning slurry as a source of 'value } \\
\text { streams, instead of problem streams'." (Doganova \& Karnøe, 2015, p. 25) }\end{array}$ & Strategy derives from vision & \\
\hline
\end{tabular}


Table 4 Illustration of the analytical framework on Maciel and Fischer (2020)

\begin{tabular}{|c|c|c|c|}
\hline & \multicolumn{3}{|c|}{ Maciel and Fischer (2020) } \\
\hline & Infusion & Formation & Retention \\
\hline \multicolumn{4}{|l|}{ Market-shaping activities } \\
\hline \multicolumn{4}{|l|}{ Modifying business model } \\
\hline \multicolumn{4}{|l|}{ Changing value proposition } \\
\hline \multicolumn{4}{|l|}{ Developing/innovating product } \\
\hline Developing vision & $\mathrm{x}$ & & \\
\hline Dissemination of market images & & $\mathrm{x}$ & \\
\hline Dissemination of market stories & & $\mathrm{x}$ & \\
\hline \multicolumn{4}{|l|}{ Introduction of a new language } \\
\hline Building relationships & & $\mathrm{x}$ & \\
\hline \multicolumn{4}{|l|}{ Entering alliances } \\
\hline Fostering collaboration & & $\mathrm{x}$ & \\
\hline \multicolumn{4}{|l|}{ Acquiring market actors } \\
\hline Including market actors & & $\mathrm{x}$ & \\
\hline \multicolumn{4}{|l|}{ Defining actor roles } \\
\hline Development and diffusion of new practices & & $\mathrm{x}$ & \\
\hline Infusion of new market norms and rules & & $\mathrm{x}$ & \\
\hline Lobbying for changes in regulations, policies or legislation & & $\mathrm{x}$ & \\
\hline Reinforcing social ties & & & $\mathrm{x}$ \\
\hline Institutionalizing practices, standards and regulations & & & $\mathrm{x}$ \\
\hline \multicolumn{4}{|l|}{ Neutralization of threats } \\
\hline Enforcing market norms & & & \\
\hline
\end{tabular}

\& Nenonen, 2011b). Since all these processes follow or are inspired by the logic of an evolutionary trajectory, we employed Dopfer et al.'s (2004) origination-adoptionretention model as an initial framework to guide our data analysis. As the case studies in the literature sample presented the analyzed market-shaping processes chronologically, they facilitated the allocation of the extracted marketshaping activities according to the analytical framework (see Table 4). In an iterative process, the different phases and allocated activities were continuously compared to test the adequacy of the utilized analytical framework. Through this process, we realized that the allocated activities represented specific phases that were not congruent with the terminology employed in previous conceptualizations. Whereas most phase models take more of a systemic point of view, our analysis focused on market-shaping processes driven by focal actors or actor groups. Consequently, the allocated activities describe active approaches to market-shaping and exhibit a mismatch with some of the established phase terms. For example, the origination phase implies emergent change rather than intentionally introduced change by a focal actor. Therefore, we chose to rename the origination phase to infusion, as most of the analyzed market-shaping processes start with a focal actor infusing change into a market. For the second phase, we adopted the term formation introduced by Fligstein (1996). In contrast to established terms such as mobilization (Storbacka \& Nenonen, 2011b) or adoption (Bleda \& Del Río, 2013), the allocated activities focus more on processes akin to market formation. For our final phase, we retained the original term of retention from the initial analytical framework, as the activities were congruent with the original terminology.

\section{Market-shaping activities-a meta-synthesis of two decades}

As discussed in the introduction, several authors have previously indicated the possible existence of phases in market-shaping processes (Jaworski et al., 2020; Kindström et al., 2018; Nenonen \& Storbacka, 2020). In the subsequent meta-analysis, we first present the extracted and aggregated market-shaping activities identified in the empirical studies and classified according to our three-phased conceptualization, starting at the infusion of market change, followed by the formation of the market and ending with the retention of the newly shaped market (see Table 5). Within the phases, we grouped the activities into clusters of activities based on their overarching purpose. After the presentation of the respective phases, we summarize our proposed three-phased framework and explore its application in ten case studies.

In our proposed framework, the market-shaping process is driven by a focal market actor or a group of aligned 
Table 5 Overview of market-shaping phases and activities

\begin{tabular}{|c|c|c|c|}
\hline Market-shaping phase & $\begin{array}{l}\text { Phase I } \\
\text { Infusion }\end{array}$ & $\begin{array}{l}\text { Phase II } \\
\text { Formation }\end{array}$ & $\begin{array}{l}\text { Phase III } \\
\text { Retention }\end{array}$ \\
\hline \multirow{16}{*}{$\begin{array}{l}\text { Activities in each phase } \\
\text { of the market-shaping } \\
\text { process }\end{array}$} & - Infusing market change & - Creating a market identity & - Increasing market resilience \\
\hline & - Modifying business model & - Disseminating market images & $\circ$ Reinforcing social ties \\
\hline & - Changing value proposition & $\circ$ Disseminating market stories & $\begin{array}{l}\text { - Institutionalizing practices, standards } \\
\text { and regulations }\end{array}$ \\
\hline & - Developing/innovating product & - Introducing a new language & \\
\hline & ○ Developing vision & & \\
\hline & & - Developing market network & $\begin{array}{l}\text { - Engaging in market-restricting } \\
\text { processes }\end{array}$ \\
\hline & & $\circ$ Building relationships & $\circ$ Neutralizing threats \\
\hline & & $\circ$ Entering alliances & $\circ$ Enforcing market norms \\
\hline & & - Fostering collaboration & \\
\hline & & - Acquiring market actors & \\
\hline & & - Including market actors & \\
\hline & & -Defining actor roles & \\
\hline & & - Influencing institutions & \\
\hline & & $\begin{array}{l}\text { Developing and diffusing new } \\
\text { practices }\end{array}$ & \\
\hline & & $\begin{array}{l}\text { - Infusion of new market norms and } \\
\text { rules }\end{array}$ & \\
\hline & & $\begin{array}{l}\text { Developing and diffusing new } \\
\text { practices }\end{array}$ & \\
\hline
\end{tabular}

market actors with the intent to herald market change. Consequently, activities in phase I are mainly firm-level activities that are often still invisible to most market actors. Once market-shaping actors have engaged in the activities in phase I, they move into the market-level and thus encounter a wide range of market actors and market activities influencing the market. Thus, phase II encompasses significantly more activities than the other phases, due to the effort required in mobilizing the multitude of market actors and activities to form the desired market (Kjellberg \& Helgesson, 2007; Storbacka \& Nenonen, 2011a). Once the market forms, the market-shaping actors enter phase III of the market-shaping process, with activities focusing on retaining the newly shaped market. As the market-shaping actors can now leverage their favorably shaped market, they do not need to engage in as many market-shaping activities as in the previous phase. Based on these insights, market-shaping becomes visible in the later phases, when market changes clearly materialize (cf. Baker \& Nenonen, 2020; Nenonen et al., 2014; Storbacka \& Nenonen, 2011b).

\section{Phase I: Infusion}

The activities categorized into the first phase of the actordriven market-shaping process can eventually lead to market-shaping but are not sufficient to shape a market (see Table 6). In our review, these activities originate primarily from individual actors and are often invisible to the market at first, as they focus on firm-level changes. However, as these changes usually occur at firm-market interfaces, they often trigger subsequent market-shaping processes.

In many cases, the introduction or modification of business models (e.g., Antone et al., 2017; Ingenbleek \& Reinders, 2013; O'Connor \& Rice, 2013), value propositions (Ghauri et al., 2016; Nenonen et al., 2020) or new product innovations are typical in heralding the infusion of market change, as it might trigger processes resulting in new market behaviors, new market actor constellations or the reconfiguration of resource flows (Jaworski et al., 2000; Nenonen et al., 2019a, b). While these activities can be regarded as materialized change, its actual materialization is dependent on the market actors' response to those activities (cf. Giesler, 2012; Nenonen et al., 2019b) (see phase II). Therefore, and since a focal market actor is usually not powerful enough to shape a market, phase I often starts with the development of an attractive vision (e.g., Baker \& Nenonen, 2020; Canales, 2016; Humphreys $\&$ Carpenter, 2018). A vision represents the desired market change and should be sufficiently enticing to mobilize market actors towards its instantiation in the next phases 
Table 6 Market-shaping activities infusing market change

\begin{tabular}{|c|c|c|}
\hline Market-shaping process & $\begin{array}{l}\text { Phase I } \\
\text { Infusion }\end{array}$ & Extracted from: \\
\hline \multirow[t]{4}{*}{ Market-shaping activities } & - Modifying business model & $\begin{array}{l}\text { Anderson et al. (2010); Ingenbleek and Reinders (2013); O'Connor and Rice } \\
\text { (2013); Antone et al. (2017); Wilden et al. (2018) }\end{array}$ \\
\hline & - Changing value proposition & Ghauri et al. (2016); Kindström et al. (2018) Nenonen et al. (2020) \\
\hline & - Developing/innovating product & $\begin{array}{l}\text { Beverland et al. (2006); Beverland et al. (2010); Ulkuniemi et al. (2015); } \\
\text { Kindström et al. (2018); Geiger and Kjellberg (2020); Ruiz and Makkar (2021) }\end{array}$ \\
\hline & - Developing vision & $\begin{array}{l}\text { Canales (2016); Humphreys and Carpenter (2018); Nenonen et al. (2019b); Baker } \\
\text { and Nenonen (2020) }\end{array}$ \\
\hline
\end{tabular}

(Gawer \& Cusumano, 2008; Jaworski et al., 2020; Reid \& De Brentani, 2010).

\section{Phase II: Formation}

The activities in the first phase are mainly focused on firmlevel changes in firm-market interfaces. However, shaping a market and thus being able to materialize the desired market change requires the mobilization (Humphreys, 2010; Maciel \& Fischer, 2020; Storbacka \& Nenonen, 2011b), alignment (Adner, 2017; Jaworski et al., 2020; Lee et al., 2018) and orchestration (Canales, 2016; Hawa et al., 2020; Mele \& Russo-Spena, 2015) of internal and external market actors and resources. In other words, it requires efforts focused on forming the market (Bleda \& Del Río, 2013; Kjellberg \& Helgesson, 2007; Storbacka \& Nenonen, 2011a). As this may result in unfavorable changes for some market actors, the introduced market change will be contested by incumbent market actors (Hietanen \& Rokka, 2015; Ingenbleek $\&$ Reinders, 2013; Regany et al., 2021). Thus, the desired market change will be in a constant level of flux between ephemerality and stability, resulting in volatile markets (Nenonen et al., 2014). Our review identified a multitude of activities that occur when market actors attempt to form a market to materialize desired market change (see Table 7). As these activities often had the same target, we have grouped them accordingly into three overarching sets of activities: creating a market identity, developing the market network and influencing institutions.

\section{Creating a market identity}

When a market is being purposefully shaped, the shaping market actors attempt to change the market representations to their favor (Geiger \& Kjellberg, 2020; Storbacka \& Nenonen, 2015). This market-shaping process is often initiated by developing a vision of the desired market that needs to be sufficiently convincing to mobilize market actors to realize it (Gawer \& Cusumano, 2008; Jaworski et al., 2020). This vision is then communicated to the market through the dissemination of market images in the form of, for example, market studies, reports or market maps (Azimont \& Araujo, 2007;

Table 7 Market-shaping activities forming the market

\begin{tabular}{|c|c|c|}
\hline Market-shaping process & $\begin{array}{l}\text { Phase II } \\
\text { Formation }\end{array}$ & Extracted from: \\
\hline \multirow[t]{3}{*}{ Market-shaping activities } & $\begin{array}{l}\text { - Creating a market identity } \\
\text { - Dissemination of market images } \\
\text { - Dissemination of market stories } \\
\text { - Introduction of new language }\end{array}$ & $\begin{array}{l}\text { Weber et al. (2008); Canales (2016); Kurland and McCaffrey (2016); Purtik } \\
\text { and Arenas (2019); Geiger and Kjellberg (2020); Maciel and Fischer (2020); } \\
\text { Breidbach and Tana (2021) }\end{array}$ \\
\hline & $\begin{array}{l}\text { - Developing market network } \\
\text { - Building relationships } \\
\text { - Entering alliances } \\
\text { - Fostering collaboration } \\
\text { - Acquiring market actors } \\
\text { - Including market actors } \\
\text { - defining actor roles }\end{array}$ & $\begin{array}{l}\text { Geiger and Finch (2009); Santos and Eisenhardt (2009); Elg et al. (2012); } \\
\text { Lawlor and Kavanagh (2015); Storbacka and Nenonen (2015); Kindström } \\
\text { et al. (2018); Wilden et al. (2018); Nenonen et al. (2019b); Kaartemo et al. } \\
\text { (2020) }\end{array}$ \\
\hline & $\begin{array}{l}\text { - Influencing institutions } \\
\text { - Development and diffusion of } \\
\text { new practices } \\
\text { - Infusion of new market norms } \\
\text { and rules } \\
\text { - Lobbying for changes in regula- } \\
\text { tions, policies or legislation }\end{array}$ & $\begin{array}{l}\text { Dewald and Truffer (2011); Canales (2016); Baker et al. (2019); Maciel and } \\
\text { Fischer (2020); Breidbach and Tana (2021); Candido et al. (2021); Ruiz and } \\
\text { Makkar (2021) }\end{array}$ \\
\hline
\end{tabular}


Kjellberg \& Olson, 2017; Storbacka \& Nenonen, 2015). Furthermore, market-shaping actors attempt to further cement and raise awareness of the envisioned market by disseminating market stories and narratives through, for example, scientific papers, media reports, books or websites (Harrison \& Kjellberg, 2010; Humphreys \& Carpenter, 2018; Maciel \& Fischer, 2020). In many cases, this is combined with the introduction of new representations and terminology to clearly distinguish the current market from the envisioned market (Rosa et al., 1999; Baker et al., 2019; Diaz Ruiz \& Makkar, 2021). These activities are often summarized as educational activities (Humphreys \& Carpenter, 2018; Nenonen et al., 2019b; Purtik \& Arenas, 2019) or market priming (O'Connor \& Rice, 2013) and are aimed at developing a clear market identity for the envisioned market (Breidbach \& Tana, 2021; Canales, 2016; Santos \& Eisenhardt, 2009; Weber et al., 2008). We perceive market identities as "strategically manufactured and managed" groups of actors sharing common perceptions and actions to generate material outcomes (Cornelissen et al., 2007, p. 9). The distinctiveness of terminology, language, market stories and market images (Cornelissen et al., 2007; Gawer \& Phillips, 2013; Wry et al., 2011), enables market actors to clearly distinguish between the current and an envisioned market, as researchers observed in the markets for grass-fed meat and dairy (Weber et al., 2008), craft-beer (Maciel \& Fischer, 2020) or local goods (Kurland \& McCaffrey, 2016). For example, craft breweries realized that they had to create a market identity in order to mobilize and orchestrate market actors towards their market-shaping goal (Maciel \& Fischer, 2020). They began to promote a shared cause through the dissemination of market images and narratives in books, magazines and websites in which they clearly communicated and "demonized" the differences between corporate breweries, the current market, and craft breweries, the envisioned market. Thereby, craft breweries' rhetoric of superiority was essential in making their cause appealing and aligning craft breweries and consumers to their vision, consequently supporting the formation of a distinguished market identity.

\section{Developing the market network}

Parallel to the creation of a market identity, market actors engage in activities to develop and modify the underlying market network. Market actors develop market networks by building relationships (Elg et al., 2012; Geiger \& Finch, 2009; Storbacka \& Nenonen, 2015), developing alliances (Lawlor \& Kavanagh, 2015; Purtik \& Arenas, 2019; Weber et al., 2008) and fostering collaboration between market actors (Kindström et al., 2018; Purtik \& Arenas, 2019; Kaartemo et al., 2020). Additionally, market-shaping actors can alter the network structure by acquiring market actors (Santos \& Eisenhardt, 2009; Wilden et al., 2018), enabling the inclusion of new actors (Humphreys, 2010; Onyas \& Ryan, 2015a; Agarwal et al., 2018) or defining their roles (Elg et al., 2012; Nenonen et al., 2019b; Purtik \& Arenas, 2019).

These network-altering activities are often carried out through the development and leverage of platforms, such as workshops (Harrison \& Kjellberg, 2010), conferences (Geiger \& Kjellberg, 2020) or trade fairs (Rinallo \& Golfetto, 2006). As these platforms bring different market actors together, they provide ample opportunity to disseminate the vision, build new connections between market actors and reinforce old relationships (Canales, 2016; Rinallo \& Golfetto, 2006).

In such instances, the aim of the market-shaping actors is twofold. First, by developing the underlying market network, they align the different market actors to the proposed vision, supporting the creation of a market identity and enabling the strategic mobilization of the market network for the materialization of the desired market change. Second, an aligned market network can pool and deploy resources in order to overcome restrictive marketshaping actors and materialize the desired market change (Beninger \& Francis, 2021; Ghauri et al., 2008; Maciel \& Fischer, 2020).

\section{Influencing institutions}

The last set of activities focuses on fostering the cohesion between market identity and market networks while paving the way for the stabilization of the desired market change. Here, market-shaping actors attempt to influence institutions due to their power to influence and maintain underlying social processes (Barley \& Tolbert, 1997; Lawrence et al., 2011). Institutions are practices, rules, norms and regulations (Lawrence et al., 2002; Scott, 2008), which encompass deeply embedded and self-activating social patterns that structure human interaction (Lawrence et al., 2002, 2011; Scott, 2008). Such institutions are created and shaped endogenously through the interaction between market actors by creating cultural templates that function as coordination devices of collective action (Araujo \& Kjellberg, 2015; Biggart \& Beamish, 2003; Fligstein, 1996; Kjellberg \& Helgesson, 2006; Vargo \& Lusch, 2016). Thus, market actors can "actively engage in processes of institutional creation, maintenance, disruption, and change", (Lawrence et al., 2011, p. 53), which will influence normative market practices and consequently shape the market (Baker \& Nenonen, 2020; Regany et al., 2021).

Thus, this set of extracted activities is similar to processes in institutional work (Lawrence et al., 2011) aimed at institutionalizing change. To materialize and stabilize the desired market change, market-shaping actors develop and diffuse new practices (Baker et al., 2019; Candido 
et al., 2021; Ruiz \& Makkar, 2021) as seen for example in the development of recycling practices to shape the polyethylene terephthalate (PET) recycling market in Brazil (Candido et al., 2021). Additionally, market-shaping actors attempt to develop new market norms and rules that support the materialization of the desired changes in the market (Breidbach \& Tana, 2021; Geiger \& Kjellberg, 2020; Purtik $\&$ Arenas, 2019). For example, digital therapeutics companies infused their market norm of continuous product development into the pharmaceutical markets they were attempting to shape, thereby changing the "rules of the game," as this change increased the pace of competition (Geiger $\&$ Kjellberg, 2020). Finally, and connected to the latter example, market-shaping actors engage in a wide range of lobbying efforts to influence regulations, policies or legislation (Dewald \& Truffer, 2011; Doganova \& Karnøe, 2015; Lawlor \& Kavanagh, 2015) due to their significant shaping power on markets.

\section{Phase III: Retention}

In the last phase, the underlying vision and the subsequent market change have been materialized and stabilized in the market. However, as markets involve continuous processes of change (Kjellberg et al., 2015; Mele et al., 2015), market-shaping actors need to engage in retention activities to maintain the shaped market (Hietanen \& Rokka, 2015; Kjellberg et al., 2015; Storbacka \& Nenonen, 2011b). In other words, while the desired market may have temporarily materialized through the activities of the focal market-shaping actors, other market actors can develop different visions of the market and engage in market-shaping processes that would destabilize the focal market-shaping actors' market. Thus, the focal market-shaping actors become market incumbents and will attempt to strengthen the market while engaging in market-restriction processes to prevent other market-shaping processes (Hietanen \& Rokka, 2015; Kjellberg et al., 2015).

These retaining activities (see Table 8) can be divided into activities aimed at increasing the resilience of the newly shaped market (Beninger \& Francis, 2021) and activities to restrict market-shaping attempts by other unaligned market actors (Hietanen \& Rokka, 2015).

\section{Increasing market resilience}

As seen in the case of Myanmar's food markets, market resilience is heavily dependent on strong, long-lasting relationships between different market actors (Beninger \& Francis, 2021). Such strong market networks can involve the communal pooling and deployment of resources in order to maintain market functioning in the face of market disturbances (Beninger \& Francis, 2021). Given the importance of maintaining a strong market network, market-shaping actors further stabilize their markets by reinforcing social ties, either through networkwide social events (Humphreys \& Carpenter, 2018; Maciel \& Fischer, 2020; Rinallo \& Golfetto, 2006) or intense personal interactions (Elg et al., 2012; Ferreira, et al., 2016; Ghauri et al., 2008).

Additionally, the institutionalization of newly introduced or influenced practices (Canales, 2016; Candido et al., 2021; Ruiz \& Makkar, 2021), standards (Elg et al., 2012; Ingenbleek \& Reinders, 2013; Ulkuniemi et al., 2015) or regulations, policies and laws (Doganova \& Karnøe, 2015; Moors et al., 2018; Maciel \& Fischer, 2020) legitimizes the newly shaped market, providing it with further cohesion, which ultimately strengthens its resilience. For example, in the Mexican small and medium enterprise (SME) credit market, market-shaping actors leveraged high-status actors to legitimize the newly developed practices of SME lending, thereby equipping the newly shaped market with institutional power and thus fortifying its raison d'être (Canales, 2016).
Table 8 Market-shaping activities maintaining the market

\begin{tabular}{lll}
\hline Market-shaping process & $\begin{array}{l}\text { Phase III } \\
\text { Retention }\end{array}$ & Extracted from: \\
\hline Market-shaping activities & - Increasing market & Ghauri et al. (2008); Beverland et al. (2010); \\
& resilience & Elg et al. (2012); Doganova and Karnøe \\
& Reinforcing social & (2015); Onyas and Ryan (2015b); Ulkuniemi \\
& ties & et al. (2015); Canales (2016); Humphreys \\
& Institutionalizing & and Carpenter (2018); Moors et al. (2018); \\
& practices, standards & Candido et al. (2021) \\
& and regulations & \\
$\bullet$ & Engaging in market- & Rinallo and Golfetto (2006); Azimont and \\
& restricting processes & Araujo (2007); Santos and Eisenhardt (2009); \\
& Neutralization of & Wilden et al. (2018); Baker and Nenonen \\
& threats & (2020); Breidbach and Tana (2021) \\
& Enforcing market & \\
& norms & \\
& &
\end{tabular}




\section{Engaging in market-restricting processes}

Here, market-shaping actors position the market as a "whole" market actor (cf. Provan et al., 2007) and leverage the previously developed and influenced market identity, network and institutions to apply coercive power or normative pressures on non-conforming market actors. To prevent any status quo-threatening market-shaping processes from emerging, the established market norms are constantly reinforced via the exertion of normative pressures in workshops (Rinallo \& Golfetto, 2006) or through the threat of market exclusion (Breidbach \& Tana, 2021). The latter activity is well illustrated in the cryptocurrency market, as only a strict adherence to the market norms provides access to processes in the market such as "initial coin offerings" (Breidbach \& Tana, 2021).

Additionally, market-shaping actors actively neutralize market threats by acquiring competitors or coercing unaligned market actors into alignment (Baker \& Nenonen, 2020; Santos \& Eisenhardt, 2009; Wilden et al., 2018). Baker and Nenonen's (2020) analysis of the introduction of the screwcap in the wine market illustrates how a strongly aligned market can coerce unaligned market actors into conformity and thus squash any emergence of opposing market-shaping processes. As the wineries in New Zealand were completely aligned regarding the introduction of screwcaps, they were able to coerce importers and distributors into acceptance despite opposition.

\section{Shaping markets-a three-phase process}

To summarize the previous analysis, market-shaping actors begin by infusing change into a specific market, attempt to align the market to this change by creating a market identity, developing market networks, and influencing institutions and, finally, retain the shaped market by continuously reinforcing and defending the stabilized change.

To illustrate and further investigate our conceptualized framework, we apply the proposed framework to ten rich, in-depth case studies included in our literature sample. We selected cases that included holistic descriptions of marketshaping processes in order to ensure market-system encompassing descriptions in the empirical data and present the results in Table 9 with summaries of the market-shaping process based on our conceptualized framework. This exploration provides further insights informing our conceptualized framework and its contextual procedure.

In all cases, the respective market-shaping process was initiated through the activities in phase I of our conceptualized framework (see Fig. 2), particularly via the development of a vision. After phase I, in which change is infused into a specific market, phase II encompasses mutually enabling and reinforcing activities in an attempt to decouple existing, change-preventing resource linkages and stabilize newly created resource linkages necessary to materialize and stabilize the desired market change (Fehrer et al., 2020; Storbacka \& Nenonen, 2011b). In this phase, market identities, market networks and institutions develop and influence each other simultaneously. Often, the creation of a market identity and the development of market networks tend to go hand-inhand, exhibiting self-reinforcing effects (Weber et al., 2008).

For example, in the craft beer market (Maciel \& Fischer, 2020) and the digital therapeutics market (Geiger \& Kjellberg, 2020), the activities performed to create a market identity through the introduction of common terminologies and the dissemination of market images in form of market reports and specialized magazines connected and linked market actors to each other. Networking events, such as conferences and workshops, further developed the market network and simultaneously supported the creation of a market identity.

Once the desired market change has been stabilized, the market-shaping process moves into the third phase of our framework, focusing on the retention of the newly shaped market. With the market being shaped according to the focal market-shapers' vision, the market-shapers then become market incumbents and consequently attempt to increase the resilience and stability of the market, while proactively engaging in market-restricting processes in order to prevent undesired market changes from materializing (Fligstein, 1996; Kjellberg et al., 2015; Nenonen \& Storbacka, 2020).

Considering that the market-shaping processes described in Table 9 followed the phases in the proposed conceptual framework, market-shaping processes can be said to be, to a certain extent, patterned. This becomes especially evident in the case of the Dutch market for sustainable coffee (Ingenbleek \& Reinders, 2013), as it illustrates a market-shaping process in which the activities of phase II are absent and not performed. Here, the market-shaping actor, Max Havelaar (MH), infused market change by introducing fair-trade coffee as a new product, developing a vision for a sustainable coffee market and directly engaging in phase III activities in an attempt to stabilize a market through the fair-trade standard. As MH did not create a market identity and did little to influence institutions or develop a market network, the incumbent market actors effectively resisted and prevented MH's desired market change from materializing by, for example, coercing all coffee roasters to refrain from collaborating with $\mathrm{MH}$. Consequently, as $\mathrm{MH}$ did not engage in phase II, they failed to align market actors towards their desired market change, resulting in the quasi non-existence of a market for sustainable coffee. With no stabilized market, many different market actors began creating market change using their own sustainability-focused standards and coffee brands, resulting in many diverse market-shaping processes that impeded the formation of a stable market for sustainable coffee.

This example, together with the exploration of the selected cases, allows for the demonstration of three key implications based on the conceptual framework. 


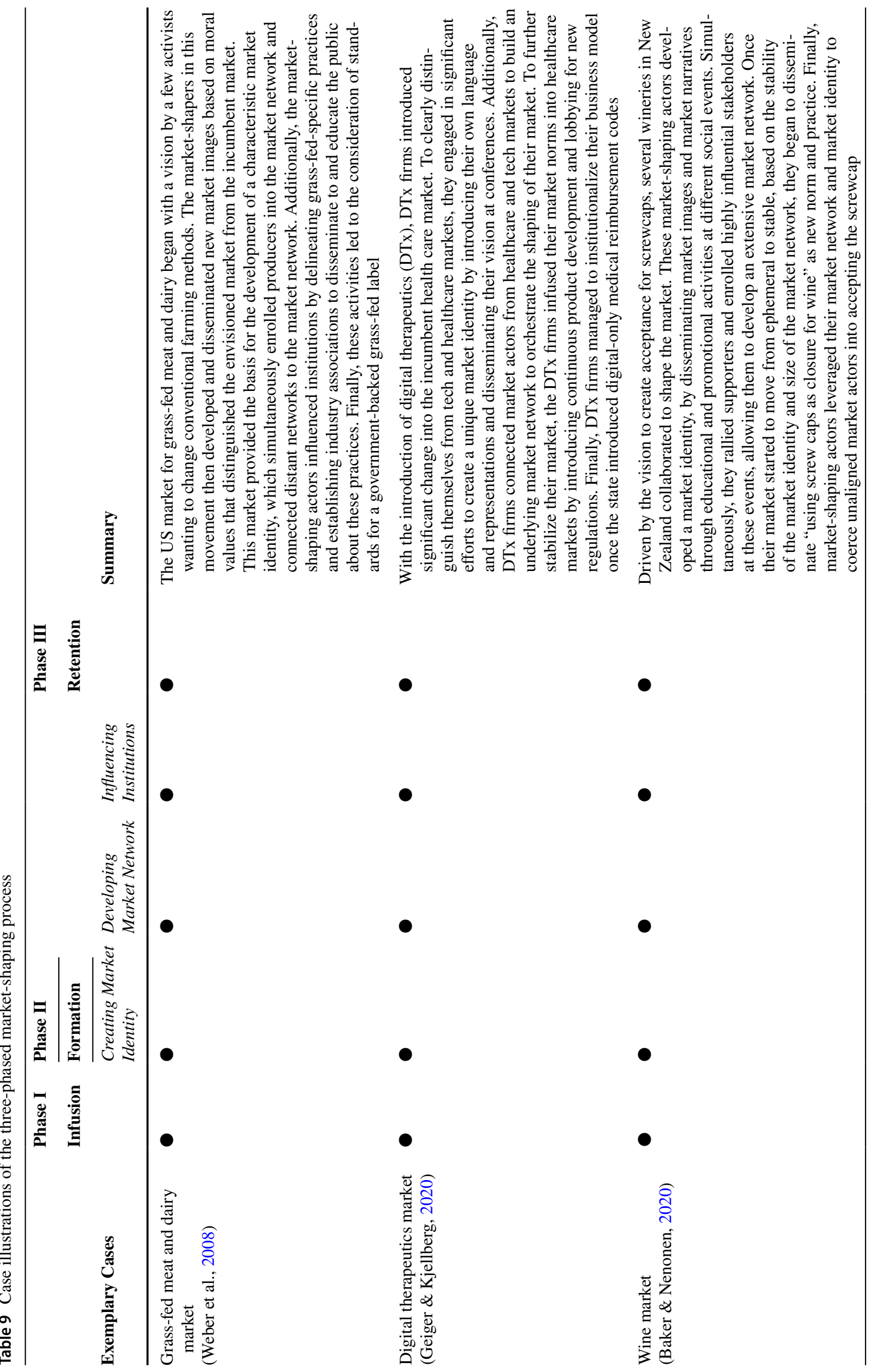




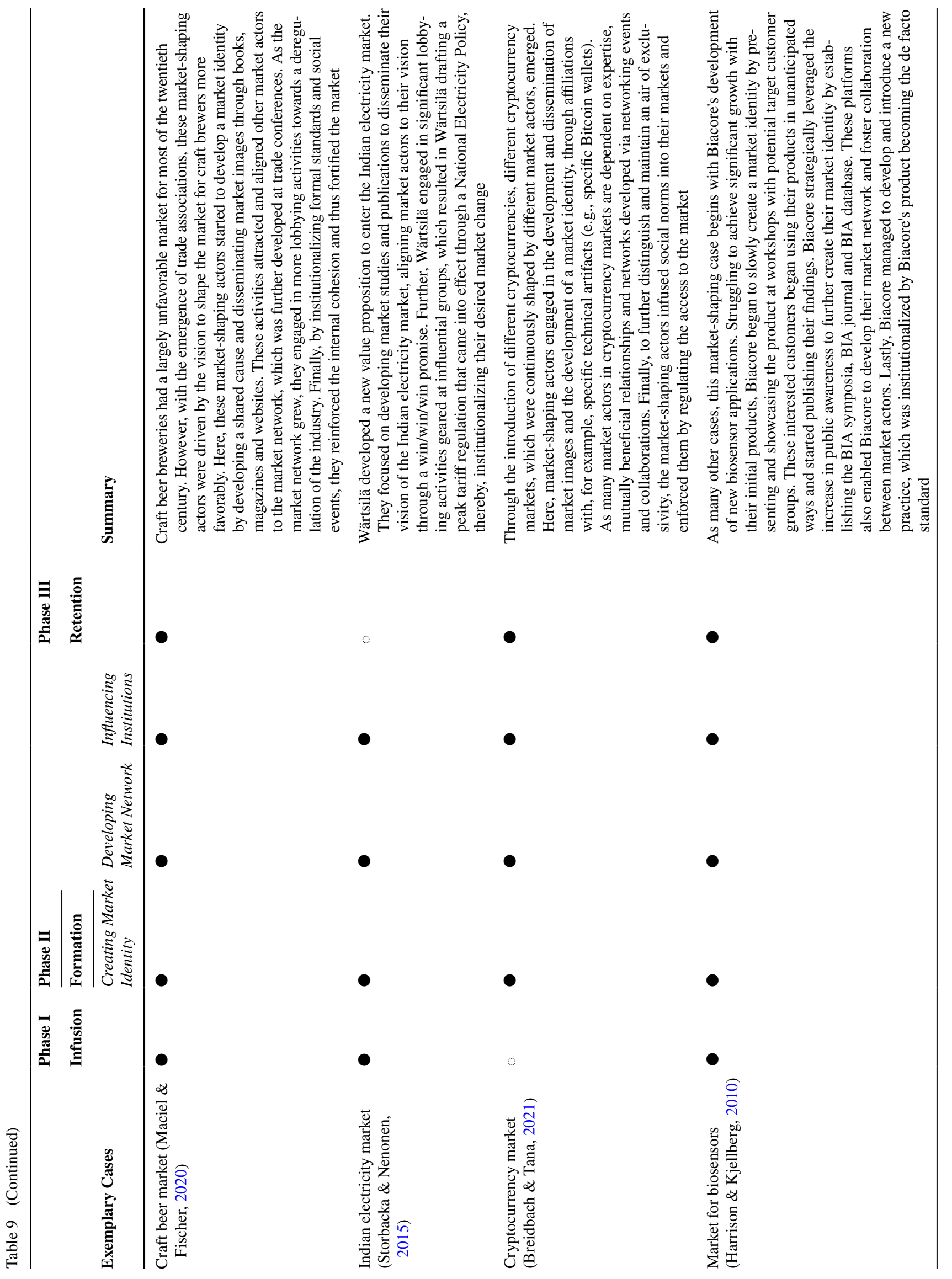




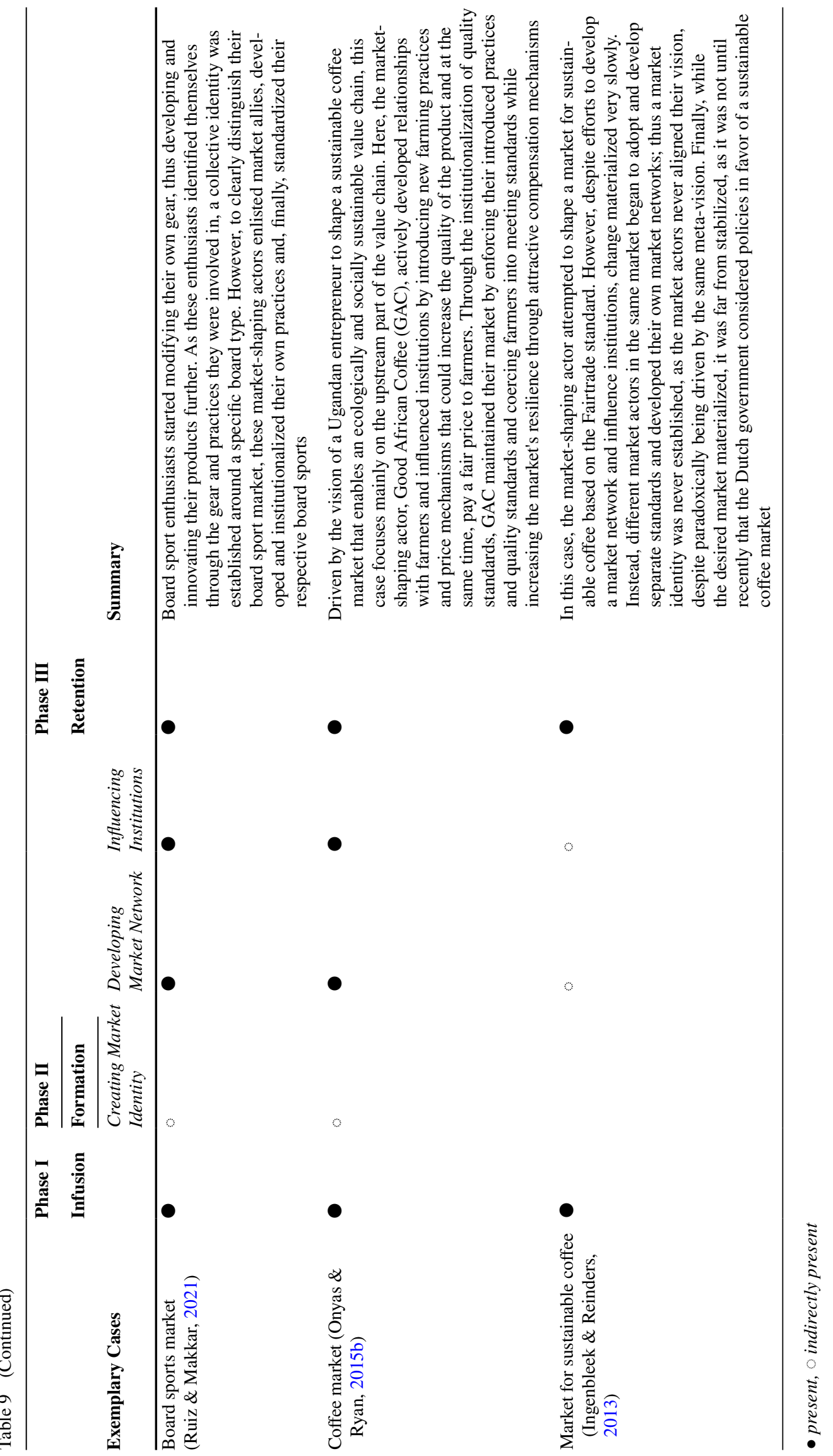


Fig. 2 Conceptualization of the three-phased market-shaping process

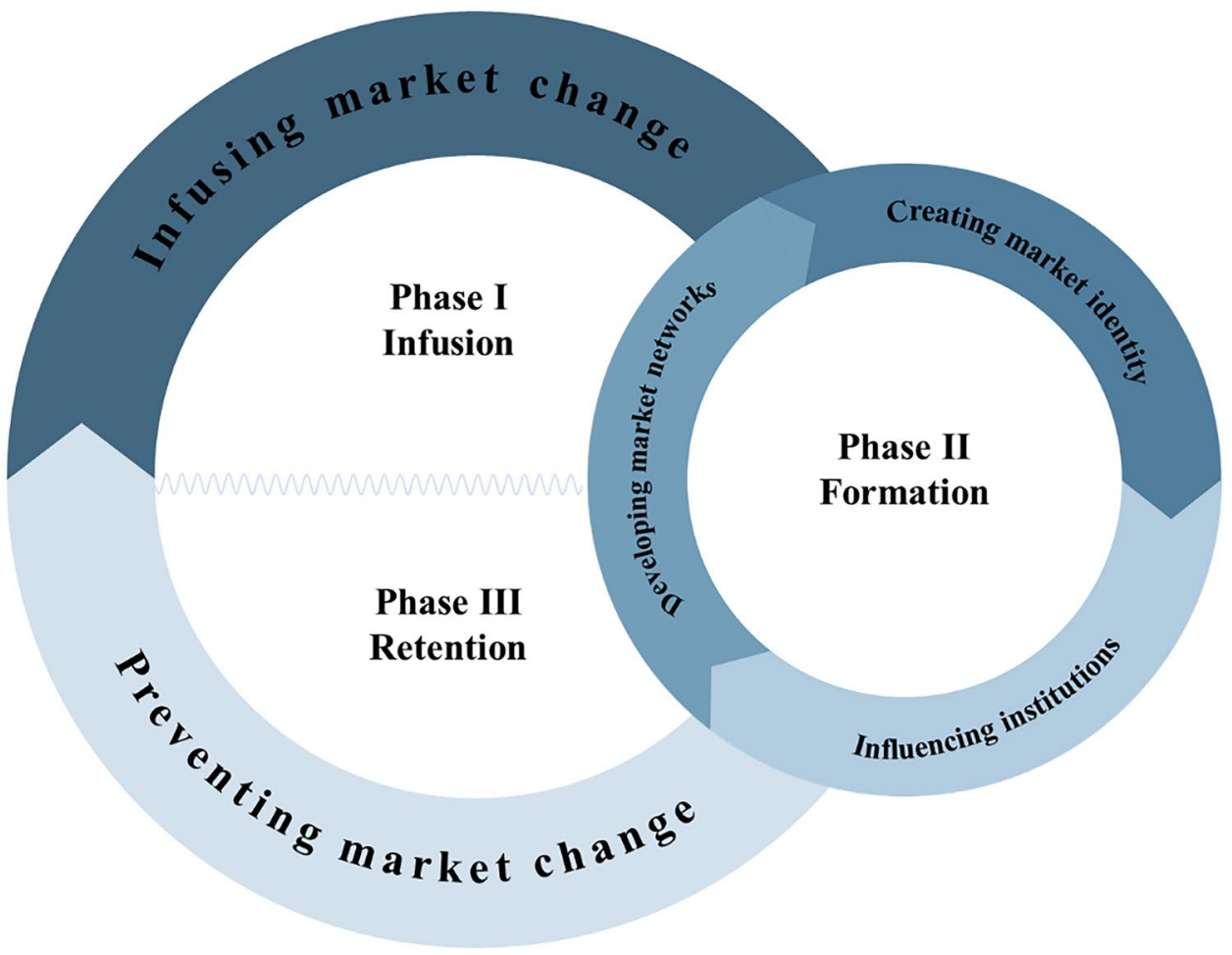

First, it illustrates and implies a degree of sequential interrelation in market-shaping processes, as the materialization of market change depends and builds upon the results of previous activities in the respective phase. Markets are constantly shaped through different activities within the wider market system, whereby activity-outcome relationships follow nonlinear pathways (Mele et al., 2015; Sprong et al., 2021). However, as some activities are dependent on the previous engagement in other activities, there are naturally inevitable patterns (cf. Geiger \& Kjellberg, 2020; Levy, 1994). For example, market actors cannot mobilize a market network if they have not previously built relationships with different market actors
(Dhanaraj \& Parkhe, 2006). Thus, our conceptualization does not focus on prediction but on different activities, processes and overarching objectives that have to be initiated and achieved to shape a market.

Second, market-shaping phases can occur simultaneously and in parallel. As previously acknowledged and argued by other market-shaping scholars, at any given time there is a multitude of different market-shaping processes influencing a market (Geiger \& Kjellberg, 2020; Hietanen \& Rokka, 2015; Kjellberg \& Helgesson, 2006). Based on our conceptualization and analysis, we perceive the multitude of market-shaping processes as different market actors

\section{Market-shaping process}

Actor 1 $\quad$ Phase I $>$ Phase II $>$ Phase III

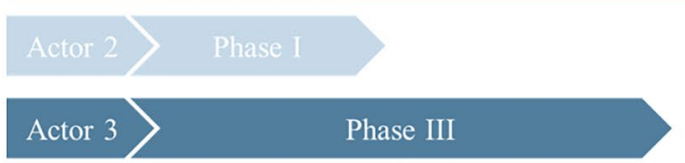

\begin{tabular}{|ccc|c|c|c|} 
Actor $4>$ Phase III $>$ Phase I \\
Actor $5>$ Phase III $>$
\end{tabular}

Fig. 3 Visualization of the multitude of co-occurring market-shaping phases 
being at different phases of the market-shaping process (see Fig. 3).

To be more precise, incumbent market actors will be focused on the retention of their market in phase III, while other marketshaping actors might either begin to infuse change by, for example, changing their business models (phase I) or attempt to form an envisioned market by trying to create a new market identity or develop a market network (phase II). Thus, the dialectic process of directing and preventing market change (Kjellberg et al., 2015) can be clarified based on the dynamics between market actors infusing market change or attempting to form a market and incumbent market actors engaging in retention activities to maintain their market.

Third, our results further emphasize the need to adopt a systemic view of markets, as the probability of successfully shaping markets seems to be highly dependent on the ability to align and mobilize a market system. While the infusion of change (phase I) does not necessitate the engagement of the market system, developing a market network, creating a market identity or influencing institutions (phase II) requires a systemic view of the market and engagement in collaborative market-shaping (Baker \& Nenonen, 2020). Thus, the possession and deployment of adequate market-shaping capabilities (Nenonen et al., 2019b), especially focused on alignment and mobilization, become critical in the formation phase. As illustrated in the case of $\mathrm{MH}$, the lack of engagement in activities in phase II or the lack of necessary capabilities can result in a failed market-shaping attempt.

\section{Conclusions and implications}

This article set out to investigate the existence of reoccurring patterns in actor-driven market-shaping processes. By conducting a qualitative meta-analysis of 79 empirical studies, the systematic synthesis of previous research indicates that the market-shaping process displays activity patterns that can be grouped into distinct phases. Taking the perspective of focal market actors with the intention of shaping a market, market-shaping can be approached as a strategic process divided into three phases unfolding over time. Based on these findings, we provide an overview of 20 analytically generalized market-shaping activities forming part of a subsequently conceptualized three-phase market-shaping process. The analysis and subsequent conceptual development have several theoretical and managerial implications.

\section{Theoretical implications}

In our first step of investigating potential reoccurring activity patterns in market-shaping processes, we set out to synthesize the extant market-shaping literature. Examining over two decades of rich qualitative studies on market-shaping processes, our meta-synthesis of the cumulative findings to date provides 20 extracted and generalized market-shaping activities.

These generalized activities indicate that there seem to be certain consistently reoccurring activities in market-shaping processes. Whereas for the most part, market-shaping literature's ontological stance argues that any activity has the capacity to shape markets, it often encumbers the generalizability and analytical strength of previously identified activities. In particular, with regard to the intentionality discussion in market-shaping (Hawa et al., 2020), it becomes difficult to establish focal activities directing a market-shaping process. Relatedly, the fuzziness of market-shaping activities and their ambiguity with regards to cause-effect relationships may result in so-called "blind spots" (Diaz Ruiz et al., 2020, p. 1389). These blind spots occur due to either too broad or too narrow interpretations of what constitutes market change, thereby obscuring focal market actors' marketshaping efforts (Diaz Ruiz et al., 2020). By synthesizing a multitude of diverse theoretical and analytical lenses, our generalized activities mitigate potential blind spots by normalizing the extant empirical evidence. Through this synthesis, the 20 generalized activities can be seen as a form of market-shaping meta-activities that strongly indicate marketshaping behavior by market actors. While our generalized activities are bounded by the respective limitations of the selected empirical studies, our synthesis is more comprehensive than any single case study could be and provides a valuable summary and necessary structure to guide the field of market-shaping forward. Especially for scholars engaging in business-oriented research, a generalized overview of empirically identified market-shaping activities constitutes a useful foundation for navigating the market-shaping field and on which to base future research.

Moreover, our investigation and subsequent development of an underlying, more structured and directed approach to market-shaping processes contribute to the market-shaping literature by further untangling the internal intricacies of an actor-driven strategic market-shaping process. The results from the qualitative meta-analysis and the subsequent illustration and exploration of the proposed conceptual framework show that a market-shaping process, as approached from a focal market actor perspective, can be perceived as a three-phased process divided into market change infusion, market formation and market retention. The reoccurrence of specific phases in non-linear complex systems, such as markets, can be informed by the notion of chaos theory (Levy, 1994). Whereas it is impossible to predict the future state of a market, markets display repetitive and reoccurring patterns that provide information about the current conditions of the market (Levy, 1994). In particular, when taking a systemic market view, frameworks inspired by evolutionary trajectories enable a structured approach to strategy development (Lovas \& Ghoshal, 2000). Relatedly, and regarding the 
notion of non-predictive strategies (Mele et al., 2015), the three-phase framework improves a firm's ability to analyze emergent market patterns and enables it to shape its strategies more adequately (Mintzberg \& Waters, 1985; Reeves et al., 2012). In other words, in a world of constant change, firms need to adopt a holistic system view, correctly read the current market trajectory and design their market strategies considering other market actors' activity patterns.

\section{Managerial implications}

For practitioners, our conceptual framework and generalized market-shaping activities may serve as managerial guidance for firms attempting to implement market-shaping strategies. By providing detailed descriptions of each phase, including the respective shaping activities evident in multiple cases, the framework informs managerial strategic planning and decision-making. It enables market-shaping to take on a more strategic role in firms and adds to the tools available to firms in their pursuit of competitive advantage. For example, the three-phase framework enables the analysis of the current market-shaping behaviors of different market actors and identifies activity patterns indicating different phases in the market-shaping process. This, among other things, allows an increased understanding of the level of resistance a focal firm may encounter when attempting to shape the market and informs the design of an adequate market-shaping strategy. Here, a first step towards designing a market-shaping strategy can be to map out the existing activities performed by the firm and its competitors and identify the respective phase.

Although market-shaping activities in phase I may be conducted by a focal market shaper, the activities in phases II and III are often based on collaborative market-shaping (Baker $\&$ Nenonen, 2020), highlighting the importance of including multiple market actors in any successful shaping process. Moreover, different market-shaping activities require different resources, making it a key managerial task to ensure the availability and mobilization of the appropriate resources and level of resources throughout the process (Nenonen et al., 2019a, b). However, as many strategic shaping activities in phases II and III necessitate the commitment and co-creative input from multiple stakeholders in order to achieve the desired market-shaping outcome (Baker \& Nenonen, 2020; Storbacka $\&$ Nenonen, 2011b), the management of resources and actors extends beyond a firm's internal organization. Consequently, managers may need to consider not only the inclusion of different organizational levels internally (Hamel \& Prahalad, 1989) but also the engagement of externally located actors (Jaworski et al., 2020; Maciel \& Fischer, 2020) to secure the appropriate resources and capabilities needed to successfully implement their market-shaping strategies.

Finally, our study implicitly suggests that a firm's marketshaping success may be as dependent on its ability to align and mobilize a market system as it is on its ability to develop or modify its individual market strategy (Nenonen et al., 2020, 2019b). While phase I tends to start with a focal actor infusing change, a frequent activity identified in this phase is the development of a vision. However, for a vision to become a reality, the vision needs to be sufficiently compelling to align and mobilize market actors towards its instantiation (Gulati et al., 2012; Jaworski et al., 2020). Thus, firms attempting to shape markets should not only focus on developing an attractive vision but also invest in developing strong alignment and mobilization capabilities. As seen in prior studies (Nenonen et al., 2019b) mobilization and alignment capabilities are crucial for the successful development and implementation of a market-shaping strategy.

\section{Future research}

The notion of a patterned market-shaping process provides ample opportunities for further research. To date, and synthesized in our overview of activities, market-shaping research has identified activities that are often employed in marketshaping processes. However, the level of differences in these activities regarding their impact on the market-shaping process remains unclear. For example, activities such as the orchestration of market actors have been proposed to potentially enable rapid market-shaping (Baker et al., 2019), thus, indicating that certain activities have more potential to accelerate the shaping of a market than others. Likewise, other activities seem to result in different market outcomes, indicating differences in power (Flaig et al., 2021). However, empirical investigations into the impact of individual marketshaping activities remain scarce. Future research could make use of the generalized activities in this study to quantitatively test the impact of the different activities on the pace and magnitude of the market-shaping process.

Furthermore, the formation phase of the proposed framework focuses on developing a market network, influencing institutions and creating a market identity. The two former foci have been extensively covered by previous studies on market networks (White, 2002; e.g., Gadde et al., 2003; Möller et al., 2020) and institutions (Lawrence \& Suddaby, 2006; e.g., Humphreys, 2010; Gawer \& Phillips, 2013). However, the creation of a market identity has received little research attention. While there have been a substantial number of studies on organizational and collective identities (e.g., Cornelissen et al., 2007; Wry et al., 2011; Thomas \& Ritala, 2021), the role and relevance of identity in a marketshaping context remains underexplored. Considering that the results from our meta-analysis highlighted the importance of creating a collective identity in order to shape a market (Breidbach \& Tana, 2021; Canales, 2016; Weber et al., 2008), most studies have focused on identity development processes until the market change materialized. However, 
how these identities unfold after the envisioned market has been materialized or if these collective identities eventually become the identity for the market can be important questions for future research inquiries.

Finally, our three-phase process framework can also extend Geiger and Kjellberg's (2020) identified patterns of interrelations between market subprocesses. Whereas their three identified types of processual interrelations - sequential, mutual reinforcement and interference-are present throughout all phases of our proposed three-phase process framework, some types might be more present in specific phases. For example, mutual reinforcement will likely be encountered in the market formation phase and especially in the retention phase, whereas interference will be characteristic of the first and last phases and mutual reinforcement in the second and third phases. Moreover, the diverse market-shaping behavior reflected in market-shaping processes can provide further insights into processual interrelations and interdependences between multiple, simultaneously occurring, market-shaping phases. Future research could combine both frameworks to further investigate the processual interrelations between multiple occurring market-shaping phases.
Funding Open access funding provided by Linköping University. The authors acknowledge the financial support of Riksbankens Jubileumsfond (The Swedish Foundation for Humanities and Social Sciences) (research grant number: P18-0588-1).

Open Access This article is licensed under a Creative Commons Attribution 4.0 International License, which permits use, sharing, adaptation, distribution and reproduction in any medium or format, as long as you give appropriate credit to the original author(s) and the source, provide a link to the Creative Commons licence, and indicate if changes were made. The images or other third party material in this article are included in the article's Creative Commons licence, unless indicated otherwise in a credit line to the material. If material is not included in the article's Creative Commons licence and your intended use is not permitted by statutory regulation or exceeds the permitted use, you will need to obtain permission directly from the copyright holder. To view a copy of this licence, visit http://creativecommons.org/licenses/by/4.0/.

\section{Appendix}

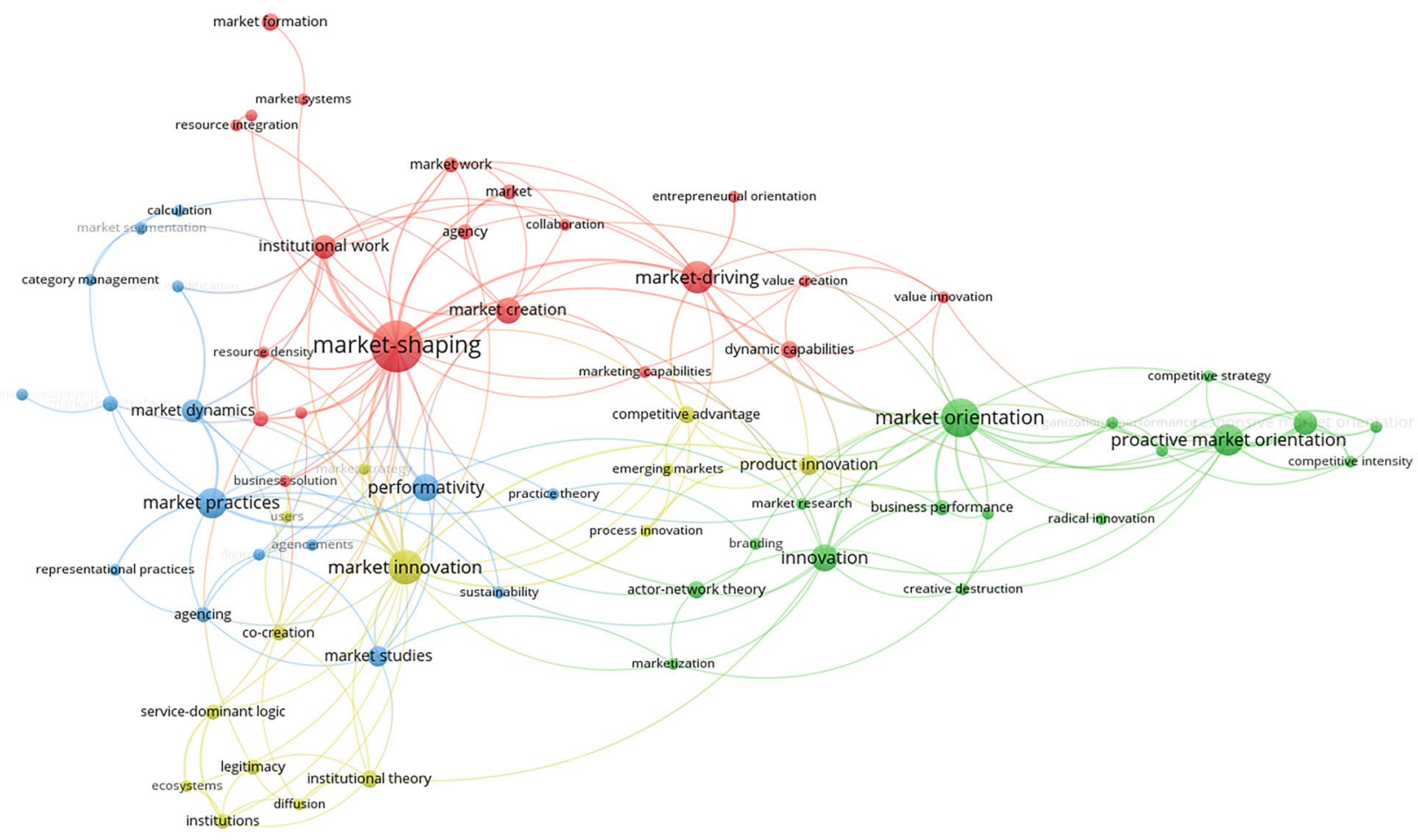

Fig. 4 Visualization co-occurrence network map of the literature sample 


\section{References}

Academic Journal Guide. (2018). In Chartered Association of Business Schools.

Adner, R. (2017). Ecosystem as structure: An actionable construct for strategy. Journal of Management, 43(1), 39-58.

Agarwal, N., Chakrabarti, R., Brem, A., \& Bocken, N. (2018). Market driving at Bottom of the Pyramid (BoP): An analysis of social enterprises from the healthcare sector. Journal of Business Research, 86, 234-244.

Alderson, W., \& Cox, R. (1948). Towards a Theory of Marketing. Journal of Marketing, 13(2), 137-153.

Anderson, J. L., Markides, C., \& Kupp, M. (2010). The last frontier: Market creation in conflict zones, deep rural areas, and urban slums. California Management Review, 52(4), 5-28.

Andersson, P., Aspenberg, K., \& Kjellberg, H. (2008). The configuration of actors in market practice. Marketing Theory, 8(1), 67-90.

Antone, S. D., Canning, L., Franklin-Johnson, E., \& Spencer, R. (2017). Concerned innovation: The ebb and flow between market and society. Industrial Marketing Management, 64, 66-78.

Araujo, L., \& Kjellberg, H. (2015). Forming cognitions by investing in a form: Frequent flyer programs in US air travel post-deregulation (1981-1991). Industrial Marketing Management, 48, 68-78.

Azimont, F., \& Araujo, L. (2007). Category reviews as market-shaping events. Industrial Marketing Management, 36, 849-860.

Babinski, T. (2004) Cirque du Soleil: 20 Years Under the Sun. New York: Harry N. Abrams.

Baker, J. J., \& Nenonen, S. (2020). Collaborating to shape markets: Emergent collective market work. Industrial Marketing Management, 85, 240-253.

Baker, J. J., Storbacka, K., \& Brodie, R. J. (2019). Markets changing, changing markets: Institutional work as market shaping. Marketing Theory, 19(3), 301-328.

Barley, S. R., \& Tolbert, P. S. (1997). Institutionalization and structuration: Studying the links between action and institution. Organization Studies, 18(1), 93-117.

Beninger, S., \& Francis, J. N. P. (2021). Collective market shaping by competitors and its contribution to market resilience. Journal of Business Research, 122, 293-303.

Beverland, M. B., Ewing, M. T., \& Matanda, M. J. (2006). Drivingmarket or market-driven? A case study analysis of the new product development practices of Chinese business-to-business firms. Industrial Marketing Management, 35(3), 383-393.

Beverland, M. B., Napoli, J., \& Farrelly, F. (2010). Can all brands innovate in the same way? A typology of brand position and innovation effort. Journal of Product Innovation Management, 27(1), 33-48

Bhaskar, R. (1998). The possibility of naturalism: A philosophical critique of the contem-porary human sciences (3rd ed.). Routledge.

Biggart, N. W., \& Beamish, T. D. (2003). The economic sociology of conventions: Habit, custom, practice, and routine in market order. Annual Review of Sociology, 29, 443-464.

Bleda, M., \& Del Río, P. (2013). The market failure and the systemic failure rationales in technological innovation systems. Research Policy, 42(5), 1039-1052.

Breidbach, C. F., \& Tana, S. (2021). Betting on Bitcoin: How social collectives shape cryptocurrency markets. Journal of Business Research, 122, 311-320.

Callon, M. (1998). The laws of the markets. Blackwell.

Canales, R. (2016). From ideals to institutions: Institutional entrepreneurship and the growth of mexican small business finance. Organization Science, 27(6), 1548-1573.

Candido, S. E. A., Sacomano Neto, M., \& Côrtes, M. R. (2021). How social inequalities shape markets: Lessons from the configuration of PET recycling practices in Brazil. Business and Society, 1-33.
Combs, J. G., Crook, T. R., \& Rauch, A. (2019). Meta-analytic research in management: Contemporary approaches, unresolved controversies, and rising standards. Journal of Management Studies, 56(1), 1-18.

Cornelissen, J. P., Haslam, S. A., \& Balmer, J. M. T. (2007). Social identity, organizational identity and corporate identity: Towards an integrated understanding of processes, patternings and products. British Journal of Management, 18, 1-16.

Depeyre, C., \& Dumez, H. (2009). A management perspective on market dynamics: Stabilizing and destabilizing strategies in the US defense industry. European Management Journal, 27(2), 90-99.

Dewald, U., \& Truffer, B. (2011). Market formation in technological innovation systems-diffusion of photovoltaic applications in Germany. Industry and Innovation, 18(3), 285-300.

Dhanaraj, C., \& Parkhe, A. (2006). Orchestrating innovation networks. Academy of Management Review, 31(3), 659-669.

Doganova, L., \& Karnøe, P. (2015). Building markets for clean technologies: Controversies, environmental concerns and economic worth. Industrial Marketing Management, 44, 22-31.

Dopfer, K., Foster, J., \& Potts, J. (2004). Micro-meso-macro. Journal of Evolutionary Economics, 14(3), 263-279.

Elg, U., Deligonul, S. Z., Ghauri, P. N., Danis, W., \& Tarnovskaya, V. (2012). Market-driving strategy implementation through global supplier relationships. Industrial Marketing Management, 41(6), 919-928.

Fehrer, J. A., Conduit, J., Plewa, C., Li, L. P., Jaakkola, E., \& Alexander, M. (2020). Market shaping dynamics: Interplay of actor engagement and institutional work. Journal of Business and Industrial Marketing, 35(9), 1425-1439.

Ferreira, F. N. H., Cova, B., Spencer, R., \& Proença, J. F. (2016). A dynamics-based approach to solutions typology: A case from the aerospace industry. Industrial Marketing Management, 58, 114-122.

Flaig, A., Kindström, D., \& Ottosson, M. (2021). Market-shaping strategies: A conceptual framework for generating market outcomes. Industrial Marketing Management, 96, 254-266.

Fligstein, N. (1996). Markets as politics: A political-cultural approach to market institutions. American Sociological Review, 61(4), 656-673.

Gadde, L. E., Huemer, L., \& Håkansson, H. (2003). Strategizing in industrial networks. Industrial Marketing Management, 32(5), 357-364.

Gawer, A., \& Cusumano, M. A. (2008). How companies become platform leaders. MIT Sloan Management Review, 49(2), 28-35.

Gawer, A., \& Phillips, N. (2013). Institutional work as logics shift: The case of Intel's transformation to platform leader. Organization Studies, 34(8), 1035-1071.

Geiger, S., \& Finch, J. (2009). Industrial sales people as market actors. Industrial Marketing Management, 38(6), 608-617.

Geiger, S., \& Kjellberg, H. (2020). Market mash ups: The process of combinatorial market innovation. Journal of Business Research, $124,445-457$.

Ghauri, P., Tarnovskaya, V., \& Elg, U. (2008). Market driving multinationals and their global sourcing network. International Marketing Review, 25(5), 504-519.

Ghauri, P., Wang, F., Elg, U., \& Rosendo-Ríos, V. (2016). Market driving strategies: Beyond localization. Journal of Business Research, 69(12), 5682-5693.

Giesler, M. (2012). How doppelgänger brand images influence the market creation process: Longitudinal insights from the rise of botox cosmetic. Journal of Marketing, 76(6), 55-68.

Gulati, R., Puranam, P., \& Tushman, M. (2012). Meta-organization design: Rethinking design in interorganizational and community context. Strategic Management Journal, 33, 571-586.

Hamel, G., \& Prahalad, C. K. (1989). Strategic intent. Harvard Business Review, 67, 63-78. 
Harrison, D., \& Kjellberg, H. (2010). Segmenting a market in the making: Industrial market segmentation as construction. Industrial Marketing Management, 39(5), 784-792.

Hawa, J., Baker, J., \& Plewa, C. (2020). Composing markets: A framework of intentionality in market-shaping. Journal of Business Research, 121, 47-57.

Hietanen, J., \& Rokka, J. (2015). Market practices in countercultural market emergence. European Journal of Marketing, 49(9/10), 1563-1588.

Hills, S. B., \& Sarin, S. (2003). From market driven to market driving: An alternate paradigm for marketing in high technology industries. Journal of Marketing Theory and Practice, 11, $13-24$.

Hoon, C. (2013). Meta-synthesis of qualitative case studies: An approach to theory building. Organizational Research Methods, 16(4), 522-556.

Hulland, J., \& Houston, M. B. (2020). Why systematic review papers and meta-analyses matter: An introduction to the special issue on generalizations in marketing. Journal of the Academy of Marketing Science, 48, 351-359.

Humphreys, A. (2010). Megamarketing: The creation of markets as a social process. Journal of Marketing, 74(2), 1-19.

Humphreys, A., \& Carpenter, G. S. (2018). Status games: Market driving through social influence in the U.S. wine industry. Journal of Marketing, 82(5), 141-159.

Ingenbleek, P. T. M., \& Reinders, M. J. (2013). The development of a market for sustainable coffee in the Netherlands: Rethinking the contribution of fair trade. Journal of Business Ethics, 113(3), 461-474.

Jaworski, B. J., Kohli, A. K., \& Sahay, A. (2000). Market-driven versus driving markets. Journal of the Academy of Marketing Science, 28(1), 45-54.

Jaworski, B. J., Kohli, A. K., \& Sarin, S. (2020). Driving markets: A typology and a seven-step approach. Industrial Marketing Management, 91, 142-151.

Kaartemo, V., Nenonen, S., \& Windahl, C. (2020). Institutional work by market-shaping public actors. Journal of Service Theory and Practice.

Kindström, D., Ottosson, M., \& Carlborg, P. (2018). Unraveling firmlevel activities for shaping markets. Industrial Marketing Management, 68, 36-45.

Kjellberg, H., Azimont, F., \& Reid, E. (2015). Market innovation processes: Balancing stability and change. Industrial Marketing Management, 44, 4-12.

Kjellberg, H., \& Helgesson, C. F. (2006). Multiple versions of markets: Multiplicity and performativity in market practice. Industrial Marketing Management, 35(7), 839-855.

Kjellberg, H., \& Helgesson, C. F. (2007). On the nature of markets and their practices. Marketing Theory, 7(2), 137-162.

Kjellberg, H., \& Olson, D. (2017). Joint markets: How adjacent markets influence the formation of regulated markets. Marketing Theory, 17(1), 95-123.

Kurland, N. B., \& McCaffrey, S. J. (2016). Social Movement Organization Leaders and the Creation of Markets for "Local" Goods. In Business and Society (Vol. 55).

Lawlor, J., \& Kavanagh, D. (2015). Infighting and fitting in: Following innovation in the stent actor - network. Industrial Marketing Management, 44, 32-41.

Lawrence, T. B., Hardy, C., \& Phillips, N. (2002). Institutional effects of interorganizational collaboration: The emergence of protoinstitutions. Academy of Management Journal, 45(1), 281-290.

Lawrence, T. B., \& Suddaby, R. (2006). Institutions and institutional work. In S. R. Clegg, C. Hardy, T. B. Lawrence, \& W. R. Nord (Eds.), Handbook of organization studies (2nd ed.). London: Sage.
Lawrence, T. B., Suddaby, R., \& Leca, B. (2011). Institutional work: Refocusing institutional studies of organization. Journal of Management Inquiry, 20(1), 52-58.

Lee, B. H., Struben, J., \& Bingham, C. B. (2018). Collective action and market formation: An integrative framework. Strategic Management Journal, 39(1), 242-266.

Levy, D. (1994). Chaos theory and strategy: Theory, application, and managerial implications. Strategic Management Journal, 15, $167-178$

Lovas, B., \& Ghoshal, S. (2000). Strategy as guided evolution. Strategic Management Journal, 21, 875-896.

Maciel, A. F., \& Fischer, E. (2020). Collaborative market driving: How peer firms can develop markets through collective action. Journal of Marketing, 84(5), 41-59.

Mele, C., Pels, J., \& Storbacka, K. (2015). A holistic market conceptualization. Journal of the Academy of Marketing Science, 43(1), $100-114$.

Mele, C., \& Russo-Spena, T. (2015). Innomediary agency and practices in shaping market innovation. Industrial Marketing Management, $44,42-53$.

Mintzberg, H., \& Waters, J. A. (1985). Of strategies, deliberate and emergent. Strategic Management Journal, 6(3), 257-272.

Möller, K., Nenonen, S., \& Storbacka, K. (2020). Networks, ecosystems, fields, market systems? Making sense of the business environment. Industrial Marketing Management, 90, 380-399.

Mollinger-Sahba, A., Flatau, P., Schepis, D., \& Purchase, S. (2021). Micro-processes of public good social innovation in the Australian social impact investment market. Industrial Marketing Management, 93, 428-445.

Moors, E. H. M., Kukk Fischer, P., Boon, W. P. C., Schellen, F., \& Negro, S. O. (2018). Institutionalisation of markets: The case of personalised cancer medicine in the Netherlands. Technological Forecasting and Social Change, 128, 133-143.

Narver, J. C., Slater, S. F., \& MacLachlan, D. L. (2004). Responsive and proactive market orientation and new-product success*. Journal of Product Innovation Management, 21(5), 334-347.

Nenonen, S., Kjellberg, H., Pels, J., Cheung, L., Lindeman, S., Mele, C., \& Storbacka, K. (2014). A new perspective on market dynamics: Market plasticity and the stability-fluidity dialectics. Marketing Theory, 14(3), 269-289.

Nenonen, S., \& Storbacka, K. (2020). Don't adapt, shape! Use the crisis to shape your minimum viable system - And the wider market. Industrial Marketing Management, 88, 265-271.

Nenonen, S., Storbacka, K., \& Frethey-Bentham, C. (2019a). Is your industrial marketing work working? Developing a composite index of market change. Industrial Marketing Management, $80,251-265$.

Nenonen, S., Storbacka, K., Sklyar, A., Frow, P., \& Payne, A. (2020). Value propositions as market-shaping devices: A qualitative comparative analysis. Industrial Marketing Management, 87, 276-290.

Nenonen, S., Storbacka, K., \& Windahl, C. (2019b). Capabilities for market-shaping: Triggering and facilitating increased value creation. Journal of the Academy of Marketing Science, 47, 617-639.

O'Connor, G. C., \& Rice, M. P. (2013). New market creation for breakthrough innovations: Enabling and constraining mechanisms. Journal of Product Innovation Management, 30(2), 209-227.

Onyas, W. I., \& Ryan, A. (2015a). Agencing markets: Actualizing ongoing market innovation. Industrial Marketing Management, 44, 13-21.

Onyas, W. I., \& Ryan, A. (2015b). Exploring the brand's world-asassemblage: The brand as a market shaping device. Journal of Marketing Management, 31(1-2), 141-166.

Podsakoff, P. M., Mackenzie, S. B., Bachrach, D. G., \& Podsakoff, N. P. (2005). The influence of management journals in the 1980s and 1990s. Strategic Management Journal, 26(5), 473-488. 
Provan, K. G., Fish, A., \& Sydow, J. (2007). Interorganizational networks at the network nevel: A review of the empirical literature on whole networks. Journal of Management, 33(3), 479-516.

Purtik, H., \& Arenas, D. (2019). Embedding social innovation: Shaping societal norms and behaviors throughout the innovation process. Business and Society, 58(5), 963-1002.

Rauch, A., van Doorn, R., \& Hulsink, W. (2014). A qualitative approach to evidence-based entrepreneurship: Theoretical considerations and an example involving business clusters. Entrepreneurship: Theory and Practice, 38(2), 333-368.

Reeves, M., Love, C., \& Tillmanns, P. (2012). Your strategy needs a strategy. Harvard Business Review, 90(9).

Regany, F., Benmecheddal, A., Belkhir, M., \& Djelassi, S. (2021). Conflicting coexistence of legitimation and delegitimation logics in a revived market: The case of a traditional clothing market. Journal of Business Research, 123, 438-449.

Reid, S. E., \& De Brentani, U. (2010). Market vision and market visioning competence: Impact on early performance for radically new, high-tech products. Journal of Product Innovation Management, 27, 500-518.

Rinallo, D., \& Golfetto, F. (2006). Representing markets: The shaping of fashion trends by French and Italian fabric companies. Industrial Marketing Management, 35(7), 856-869.

Rosa, J. A., Porac, J. F., Runser-Spanjol, J., \& Saxon, M. S. (1999). Sociocognitive dynamics in a product market. Journal of Marketing, 63, 64-77.

Rousseau, D. M., Manning, J., \& Denyer, D. (2008). Evidence in management and organizational science: Assembling the field's full weight of scientific knowledge through syntheses. The Academy of Management Annals, 2(1), 475-515.

Diaz Ruiz, C. A., Baker, J. J., Mason, K., \& Tierney, K. (2020). Marketscanning and market-shaping: Why are firms blindsided by marketshaping acts? Journal of Business \& Industrial Marketing, 35(9), 1389-1401.

Diaz Ruiz, C. A. , \& Makkar, M. (2021). Market bifurcations in board sports: How consumers shape markets through boundary work. Journal of Business Research, 122, 38-50.

Santos, F. M., \& Eisenhardt, K. M. (2009). Constructing markets and shaping boundaries: Entrepreneurial power in nascent fields. Academy of Management Journal, 52(4), 643-671.

Scott, W. R. (2008). Institutions and organizations: Ideas and interests. Sage Publications Inc.

Snyder, H. (2019). Literature review as a research methodology: An overview and guidelines. Journal of Business Research, 104(August), 333-339.

Sprong, N., Driessen, P. H., Hillebrand, B., \& Molner, S. (2021). Market innovation: A literature review and new research directions. Journal of Business Research, 123, 450-462.
Storbacka, K., \& Nenonen, S. (2011a). Markets as configurations. European Journal of Marketing, 45(1), 241-258.

Storbacka, K., \& Nenonen, S. (2011b). Scripting markets: From value propositions to market propositions. Industrial Marketing Management, 40, 255-266.

Storbacka, K., \& Nenonen, S. (2015). Learning with the market: Facilitating market innovation. Industrial Marketing Management, 44, $73-82$.

Struben, J., Lee, B. H., \& Bingham, C. B. (2020). Collective action problems and resource allocation during market formation. Strategy Science, 5(3), 245-270.

Thomas, L. D. W., \& Ritala, P. (2021). Ecosystem Legitimacy Emergence: A Collective Action View. Journal of Management, 1-27.

Tranfield, D., Denyer, D., \& Smart, P. (2003). Towards a methodology for developing evidence-informed management knowledge by means of systematic review. British Journal of Management, 14(3), 207-222.

Ulkuniemi, P., Araujo, L., \& Tähtinen, J. (2015). Purchasing as marketshaping: The case of component-based software engineering. Industrial Marketing Management, 44, 54-62.

Vargo, S. L., \& Lusch, R. F. (2016). Institutions and axioms: An extension and update of service-dominant logic. Journal of the Academy of Marketing Science, 44(1), 5-23.

Watson, R., Wilson, H. N., Smart, P., \& Macdonald, E. K. (2018). Harnessing difference: A capability-based framework for stakeholder engagement in environmental innovation. Journal of Product Innovation Management, 35(2), 254-279.

Weber, K., Heinze, K. L., \& Desoucey, M. (2008). Forage for thought: Mobilizing codes in the movement for grass-fed meat and dairy products. Administrative Science Quarterly, 53, 529-567.

White, H. C. (2002). Markets from networks: Socioeconomic models of production. Princeton University Press.

Wieland, H., Nariswari, A., \& Archpru, M. (2021). On managerial relevance: reconciling the academic - practitioner divide through market theorizing. AMS Review.

Wilden, R., Gudergan, S., \& Lings, I. (2018). The interplay and growth implications of dynamic capabilities and market orientation. Industrial Marketing Management, 83, 21-30.

Wry, T., Lounsbury, M., \& Glynn, M. A. (2011). Legitimating nascent collective identities : Coordinating cultural entrepreneurship. Organization Science, 22(2), 449-463.

Zupic, I., \& Čater, T. (2015). Bibliometric methods in management and organization. Organizational Research Methods, 18(3), 429-472.

Publisher's Note Springer Nature remains neutral with regard to jurisdictional claims in published maps and institutional affiliations. 